\title{
A Poem and its Self-translation
}

\section{Introduction}

"Poema II/ Poem II", a bilingual expression that goes beyond a mere literary translation, is part of the series Poetízame las ganas/Turn My Yearnings into Poetry. Although it started as an original poem in Spanish, my first language, an English translation ended up coming together from the first lines. Very much influenced by the playful translations of Eliot Weibenger into English, I enjoy playing with source and target languages to puzzle the reader, by erasing the traces of the translation process, while, at the same time, keeping a foreign debris within the kind of
Sofía Monzón University of Alberta

language I use in both texts. With these two pieces that arise as a reciprocated translation, the poet challenges a bilingual form of creative expression in which there is a clear refusal to utterly domesticate the texts. Love and language are, undoubtedly, both the object and the subject of the whole poem. They are represented through an unceasing analogy that depicts the symbolic connections behind these two intrinsic, most desired-and perhaps hardest to understand - human domains. 


\section{Poetízame las ganas, "Poema II"}

Déjame ser sujeto

verbo y predicado

yo adornaré nuestra cópula

en el condicional y hasta en el pasado

te prometo definiciones compuestas

subjetivas, orgánicas o sincrónicas,

evoluciones causales, temporales

e incluso proposiciones filosóficas

léeme la cláusula de tu vida

$$
\begin{aligned}
& \text { tu nombre } \\
& \text { tu elemento, }
\end{aligned}
$$

ven a ser mis cardinales

o mis ordinales carnales

o mi saliva en complemento

quiero que en imperativo

tus futuros se coordinen adverbialmente

con mis posibles subjuntivos

que nuestro léxico se renueve

y sea causativo, flexible, adversativo

con sitio siempre para un par

$$
\text { de preposiciones }
$$

y un sinfín de sufijos aumentativos

quiero que sumemos

que usemos las comas

y los puntos suspensivos,

que me escribas entre líneas

entre piernas

entre versos

entre besos

con labios multilingües

y caricias sin signos interrogativos

\section{Turn My Yearning into Poetry, "Poem II"}

Let me be subject

verb and predicate,

I will adorn our copula

in conditional and in past tense

I promise you compound definitions

subjective, organic, synchronic, casual or causal resolutions or even

philosophical matters

read me the clause of your life

your noun

your element,

be my cardinal number

my carnal ordinal or come

to complete my cadence

I want that in imperative

your futures coordinate

adverbially

with all my possible tenses, and that our lexicon can upgrade and be causative, flexible, appositive, with infinite room for a pair of propositions

and endless augmentative suffixes

I want us to add, to use commas

and ellipsis;

for you to write me between lines

between legs

between verses

between kisses

with multilingual lips

free of any interrogative 
que me respondas casi siempre

$$
\text { en afirmativo }
$$

que me rebatas algunas veces

$$
\text { en argumentativo }
$$

y nunca te olvides

de que soy texto y oralidad

sin ser exclusivos;

yo rimaré mi género y número

con tu apartado masculino

que es mi continente

y es tu contenido

porque deseo que se nos cumplan

al tiempo, los hipotéticos causativos para que me declines cada noche en genitivo en vocativo

o dejes espacio para algún que otro

superlativo

que las elipsis que nos surjan

no sean relativas

sino el resultado firme

de nuestros orgasmos apelativos

y que si comparas,

nunca haya lugar para los peyorativos

solo quiéreme

y quiéreme sólo siempre:

en presente

en futuro

en modo definitivo.
I want you to respond most times in affirmative

but to always refute me solely

$$
\text { in argumentative }
$$

and never forget

that I am text and orality

though they aren't exclusive;

I will agree my gender and content

with your masculine distinction

which is of your continent

my favorite region

for I want that, with time, we fulfill our hypothetical causatives so that you can decline me every night

$$
\text { in genitive }
$$

in vocative

and leave space only for one or two

superlatives

I want that the omissions we face

aren't relative,

just a firm result

of our orgasms in appellative

and that, if you compare,

there would never be room for

pejoratives,

only love me

and love me only for ever:

in present

in future

without any restriction. 